\title{
〔特集 パラダイム論】
}

\section{「パラダイム論」の必然性}

黒崎宏*

\section{1}

1957年の春, ジョン・ウィズダム（John Wisdom）は バージニア大学に招かれて, 大学院の学生や大学のスタ ッフを相手に，「証明と説明 (Proof and Explanation)」 といら題目のもとに一連の講義を行なった。「バージニ ア・レクチュアース (Virginia Lectures)」と言われるそ の講義では, 多くの哲学上の話題がとり上げられたが, 特に認識, 普遍, パラドックス, 形而上学, 分析一総合 の区別, 懷疑論, 誤り, 言明, ボーダーライン・ケイ ス, 㷌納法, といった話題については，すべて或る程度 詳しく論じられた。しかし，それらの話題を貫欢き，そ して「証明と説明」といら題目にまで及んでいる中心テ 一マは, 彼が「ケイス・バイ・ケースの方法 (case-bycase procedure)」とか「相似物に基づいた推論(reasoning by parallels)」とか言ったものであった。そしてこのテ 一マに関する彼の議論は, 出席していた人々を大い驚 かしたよらであり，またウイズダム自身，人々に衝撃を 与えることを狙っていたようである。

以下の私の議論は, そのウィズダの議論—といって もそれは出版されてはいず, したがって,ただ間接的に推 测され得るにすぎないものである”一一を，私なりに， 私自身に納得のゆくまで歪めたり，拡大したり，縮小し たりして再構成しそとしてそこから「パラダイム論」の 必然性を見てとろらとするものである。したがって以下 の私の議論は, ウイズダの名を借りた私の議論である, といった性格のものであり, 若干の用語と問いの立て方 と結論以外は, 例も表現方法も議論の展開の仕方も, 寸 べて私自身のものである。

\section{2}

単純なる「㷌納的推論」一例觉ば「 $I_{m}$ だから $J_{m}$ で あろら」一の場合には, 我々はそれと「類似」な事例 —「 $I_{1}$ のとき $J_{1}$ であった」, 「 $I_{2}$ のとき $J_{2}$ であっ

\footnotetext{
* 成城大学
}

た」，…‥に基づいて推論をする。したがってこの種 の単純なる帰納的推論は, いわば,「類似物（「I1 のとき $J_{1}$ であった」，「I $I_{2}$ のとき $J_{2}$ であった」，…...) に基ついい た推論 (reasoning by analogy)」と言うことが出来よ う。そしてこの点については，一応問題はあるまい。る ちろん, この種の単純なる帰納的推論といえども, それ をそう簡単に片づけてしまうためには，それ相当の議論 をつけ加えて扔かねばならないであろう。しかし，今は その時ではない。この点については, 別に機会を持ちた いと思う ${ }^{2)}$ 。

ところでウイズダムは,「演綽的推論」一一例えば「 $D_{m}$ だから $E_{m}$ である」一の場合にも，似たようなことを 言うのである。すなわち彼は, 演繹的推論の場合にも， 我々は，それと似た事例—「 $「 D_{1}$ のとき $E_{1}$ である」，

$\Gamma D_{2}$ のとき $E_{2}$ である」，……）に基ついて推論をする のだ，と言らのである。しかし実は彼は，演繹的推論の 場合には，「類似物」といら語の代りに「相似物」とい ら語を用いる。したがって彼によれば，演繹的推論と

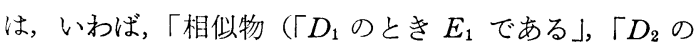
とき $E_{2}$ である」，……) に基づいた推論」と言わるべき ものなのである。

しからば,「類似物」と「相似物」はどら違うのか。 それは, 前者は現実のものに限られるのに対し, 後者は そうではない,といら事である。帰納的推論の場合に頼 られるべき事例は，現実に起こったものでなくてはなら ない。単に想像されただけの事例では, 帰納的推論の根 拠にはなり得ない。「思考実験」は, 実は実験ではない, というわけである。したがって当然, 帰納的推論を「類 似物に基づいた推論」と言らとすれば，「類似物」とは, 現実のもの一一現実は生起したもの一一限られねばな らないのである。ところが演繹的推論の場合には, この 条件は不必要である。演繹的推論は, 現実の世界一現 実に生起したこの世界一に関わりなく，いわば可能的 世界においてる, 成り立つからである。そこでウイズダ 
ムは，演繹的推論の場合にはそれを，「類似物に基つい た推論」とは言わないで，「相似物に基づいた推論」と 言ったのである。

このよらなウイズダムの議論は, 彼の講義に出席して いた人々を，大いに驚かしたようである。なぜならそれ は，大いに常識に反していたから。

たしかに,「I 帰納的推論の場合には，それを「积のとき $J_{1}$ であっ た」，「 $I_{2}$ のとさ $J_{2}$ であった」，…‥といった類似物に基 づいた推論とみる事は出来よう。この場合「一般に，

もし $I_{n}$ ならば $J_{n}$ である」といった一般的な「経験法 則」に訴光たところで，事態は同じなのである。なぜな ら，我々はここで，一体その経験法則は当の州納的推論 を含んでいるのだろらか，という問いを立ててみるとよ い。もしこの経験法則が当の帰納的推論 $(n=m$ の場合) を含んでいるとすれば，そして，その経験法則に訴兄る ことが，そこに含まれている当の帰納的推論に訴兄るこ とであるとすれば，この訴光は循環していることにな りまた，もしその経験法則に訴えることが，そこに含 まれている当の帰納的推論に訴えることでないとすれ ば，あるいは，その経験法則が当の帰納的 推論 $(n=m$ の場合）を含んでいないとすれば，結局我々は, 形の上 では経験法則に訴えていながら，その実は「 $I_{1}$ のとき $J_{1}$ であった」，「I $I_{2}$ のとき $J_{2}$ であった」, …いっった 類似物に訴えているにすぎない事になるから。一般的に 言えば，個々の具体的な帰納的推論に敃いては, 経験的 な二般法則は不必要である，といら事になるのである。

単純な帰納的推論についてのこの様な見解は, ヒュ一 么以降は, 比較的常識的であると言えよう。

ところがウイズダムは,「衝撃的同類性 (shocking affnity)」といら言葉を用いながら ${ }^{3)}$ ，同様のことが演繹的 推論の場合にも言えるのだ，と言うのであり，そしてこ れは，大いに常識に反していたのである。なぜなら一般 には，「D だから $E_{m}$ である」といった演繹的推論 の場合には，我々はこの推論を，「 $D_{1}$ のとさ $E_{1}$ であ る」，「 $D_{2}$ のとき $E_{2}$ である」，…といった相似物に基 ついて行ならのではなく,「数学の法則」や「論理の法 則」に訴えて行ならのであり，そこに拈いては，それら の法則———般法則」一—不可欠の役割を演じてい ると思わ礼ていたから。

ところがウイズダムによれば，「D $D_{m}$ だから $E_{m}$ であ る」といった演繹的推論の場合も，それは，類似物では


る」…‥といった相似物に基づた推論であり，この場
合,「一般に,もし $D_{n}$ ならば $E_{n}$ である」といった数 学や論理学の一般法則に訴えたところで, 州納的推論の 場合々同様に，事態は同じなのである。そしてその理由 も,ささの単純な帰納的推論の場命と, 絬局は闹様なの である。

それ功光，もしウイズダムの言うことが受け入れられ るとすれば,ウイズダムは演繹に打けるとュームである, という事になるであろう。しからば，実際にはどうなの であららか。

\section{3 の 1}

例兊ば，我々は或る（凸の）10角形の図形を眼前にし ているとしょう。そして問題は，その10角形の図形の対 角線は何本か，という事であるとしょう。この場合我々 は抢そらく，その10角形の図形に実際に対角線を引い て，その本数を数光る，といら事はしまい。そんな事を しては，おそらく出て来る結果にはバラッキができ，自 信がもてないであろうし，第一，大変な手間がかかるか ら。しからば我々は，実際にはどうするであるらか。

その一つの仕方は，拈そらく，多角形の解之それの 対角線の本数の関係

\begin{tabular}{l|l|l|l|l|l|l} 
角 数 & 3 & 4 & 5 & 6 & 7 & $\cdots$ \\
\hline 対角線の本数 & 0 & 2 & 5 & 9 & 14 & $\cdots$
\end{tabular}

を用いるか，またはこれの代数的表現としての

$n$ 角形の対角線の本数 $=\frac{n(n-3)}{2}$

但し, $n=3,4,5,6,7 \cdots \cdots$

という数学の一般法則に訴光ることであるう。そして後 者の場合には我々は，nのところに10を代入して計算を すれば

$$
\frac{10 \times(10-3)}{2}=35
$$

であるから，35という签が，いとも簡単に得られるので ある。そして確かにこの例は,「D だから $E_{m}$ (この図形の対角線は35本) である」という 演繹的推論を, 数学の一般法則「一般に, もし $D_{n}$ (こ の図形が $n$ 角形) ならば $E_{n}$ (この図形の対角線は $n(n$ -3)/2本)である」4) 汇訴光て行なっている例であり， かつこの一般法則は, 10角形が百角形, 千角形ともなれ ば，もはや不可欠な役割を演じるようになる，と思わ机 るのである。

ところがウイズダムならばここにおいて，さきの㷌納 的推論の場合と同じ問いを，あ充て持ち州すであうう。 
一体その数学の一般法則なるものは, 当の演繹的推論 （ $n=10$ の場合）を含んでいるのだろらか，亡。この問

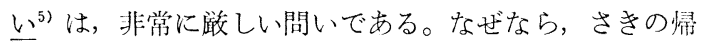
納的推論の場合と同様に，もし含んでいるとすれば，そ して，その一般法則に訴光ることが，そこに含まれてい る当の演繹的推論汇訴えることであるとすれば，その一 般法則に訴光ることは循環になり，また，もしその一般 法則に訴えることが，そこに含まれている当の演繹的推 論涪訴觉るとでないとすれば，あるいは，その一般法 則が当の演繹的推論（ $n=10$ 場合）を含んでいないと 士れば，結局我々は，形の上ではその一般法則に訴兄て はいるが，その先は「 $D_{1}$ のとき $E_{1}$ である」，「 $D_{2}$ のと き $E_{2}$ である」，……いった相似物に訴兄ているにすぎ ない事になるから。要するに、いずれにせよさきの数学 の一般法則なるものは, 実際上は何の働きもしていない 事になるのである。一般的汇言党ば，個々の具体的な演 繹的推論においては, 数学の一般法則なるものは不必要 である、といら車になるのである。

これに対して，例えば次のよらに筌えたくなるである う。そのような事が問題になるのは，元もそもその数学 の一般法則なるものが，数学の内部においてではある が，笑は未だいわば「経験法则」の段階にあるからであ り，したがって，ここで「演繹的推論」と言われている ものは，尖は米だ「齊納的推論」であるからであって， 一度その数学の一般法則なるものが数学的に「証明」せ られ，真の意味で，一般に成り立つ数学の一般法則にな ったならば，そのよらな問題は消滅してしまう，と。そ して実際に，その姫明をしてみせるのである。それは例 てば，次のようなものであろら。

「n解形では，一つの頂点からは，自分自身とその雨

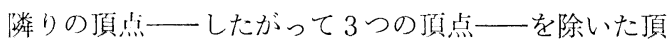
梷へ対伯線を引くことが出来るから， $n-3$ 本の対角 線を引くことが出来る。そして同様のことが $n$ 個の頂 梷について夫々党る。したがって各頂点から夫々 $n$ - 3 本の対角線を引けば，企部で $(n-3) \times n$ 本の対 解線が引けることになる。ところが，そうすると二つ の頂点の間には二本の対角線が引かれることになるか ら, 奏際の対角線の本数はその半分である。したがっ て， $n$ 角形の対㑬線の本数は

$$
(n-3) \times n \div 2
$$

すなわり

$$
n\left(\frac{n-3)}{2}\right.
$$

である。(証明終り)」

\section{3 の 2}

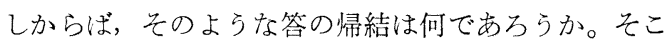
で，さきの「証明」について見てみよう。するとそれは 3 角形, 4 角形, 5 角形……についての夫々の証明を, いわば一括して行なったといら事なのである，といら事 がわかる。なぜなら， n角形という図形は実際には存在 しないいであり, 実際に存在するのは, 3 角形, 4 角形, 5 角形……゙あるるのだから。したがって，さきの証明に は, 10角形の場合の証明も当然含まれているのであり, 実際，さきの証明で $n$ のところに10を代入すれば，それ がまさに10角形の場合の証明になるのである。このこと は何を物語っているのか。それは, さきの数学の一般法 則は, 当の演繹的推論 ( $n=10$ の場合) を当然含んでお り，そしてその一般法則に訴光ることは，そこに含まれ ている当の演繹的推論に訴光ることである，という事で あろう。しかし，今や我々は，当の演繹的推論の証明を 知っているのである。したがって，さきの数学の一般法 則に訴えることは，そこに含まれている当の演繹的推論 飞訴光ることである，と言ったとしても，そこで言われ ている事は，その実は，当の演繹的推論の「証明」—— $n=10$ 場合の証明——訴兄る，といら事に外ならな いのである。したがって，一般法則に訴えることが，そ こに含まれている当の演繹的推論に訴兄ることであると しても，この場合は，決して循環になりはしないのであ る。そして確かに，こう考光れば，さきのウイズダムの 問い対しては，一応の答を得たことになるであろら。

しかし，以上の上うであるとすれば，「D である」といった演繹的推論の場合，それを「一般に， もし $D_{n}$ ならば $E_{n}$ である」といった数学の一般法則に 訴光るという事は，その実は，「むし $D_{m}$ ならば $E_{m}$ で ある」という事の証明に訴光るといら事，言うなれば， 当の演繹的推論自身の証明に訴光るといら事であって, ここに扔いては, 一般的な数学の法則は本来必要ないこ とになる。さきの例で言光ば,「この図形は10角形だ から，この図形の対角線は35本である」という演繹的推 論をするには，さきの証明に执いてnのところに10を代 入した証明に訴えれば，それでよいのであって，nのと ころにその他の数を代入した証明はこの場合不必要なの であり，したがってこの場合， nをnのままにした一般 的な証明も不必要なのである。そしてそれゆ光，それに よって証明されると言われるとこちの，「一般に，もし $D_{n}$ ならば $E_{n}$ である」といった一般的な数学の法則も， 本来必要がないことになるのである。一般的に言えば， 個々の具体的な演繹的推論においては, 依然として, 数 
学の一般法則は不必要である, という事になるのであ る。

この場合，とにかく何らかの仕方で「一般法則」を救 わんとして，nのところに10を代入した証明は， $n$ を $n$ のままにした二般的証明の特殊な場合であって，したが って，前者は後者に訴えて得られたものであり，それゆ え, 後者が証明する一般法則は不必要ではない, と言っ たところで無䭾である。なぜなら，たしかに形式的に は, 前者は後者から導かれるとはいえ, 前者は, 後者に 訴えて得られたものではないからである。第一，前者は 後者に訴えよらがないのである。そしてこの事は，再び ウイズダムにならって言えば，もしその一般的証明に訴 えることが，そこに含まれている当の特殊な証明に訴兄 ることであるとすれば，その訴光は循環になり，また，も しその一般的証明に訴えることがそこに含まれている当 の特殊な証明に訴えることではないとすれば，結局我々 は，形の上ではその一般的証明に訴えてはいるが，その 実は, $n=3$ の場合， $n=4$ の場合，…といった相似 物に訴えているにすぎない事になるのだ，といら事から 明らかであろう。いずれにせよ，特殊な証明は一般的証 明には訴えようがないのであり，したがって特殊な証明 のためには一般的証明は不必要なのであって, それゆえ この点からしても，一般法則は不必要なのである。

\section{3 の 3}

しからば，実際にはどらなっているのだろらか。たし かに， $n=10$ の場合の演繹的推論「この図形は10角形た から，この図形の対角線は35本である」には，「一般に， むし $D_{n}$ (この図形が $n$ 角形) ならば $E_{n}$ (この図形の対 角線は $n(n-3) / 2$ 本) である」といった二般法則は不 必要なのである。そこに必要なのは，自分自身の「証明」 なのである。そしてたしかに， $n=10$ 場合の証明は， 或る意味で，それ自身で成立していると言えよう。それ は，他のそれと相似な場合の証明に訴える必要もないの である。しかしここで，ウイズダムならば言うであろ う。その証明の「理解」は，より簡単なそれと相似な場 合の証明の理解に基づいているのだ6)，と。そして，確 かにその通りである。なぜなら， $n=4, \quad n=5, \quad n=6$ といった簡単な場合の証明の理解なしには, $n=10$ とい った複雑な場合の証明の理解はあり得ないから。そして 実際，例えば $n=10$ 場合の証明を理解できない人がい た場合，その人にその証明を理解させるには，我々はそ の人を，簡単な場合の証明から複雑な場合のそれへと， 上手に誘導するより他に仕様がないから。例えば我々は
その人に, $n=4$ の場合の証明からはじめ, $n=5$ の場 合, $n=6$ の場合と，ステップ・バイ・ステップによ り複雑な証明を理解させるわけである。そして或る所ま で来て，例党ば $n=6$ の場合まで来て，あとは「以下同 様」と言って，その人を突きはなし， $n=10$ の場合の証 明を自ら理解させるのである。技そらく普通ならばそれ で，その人は $n=10$ 場合の証明を自ら理解するである 5。

しからば，なぜ $n=4, n=5, n=6$ といった簡単 な場合の証明なしには, $n=10$ といった複雑な場合の証 明の理解はあり得ず, しかし, 例えばステップ・バイ・ ステップに簡単な場合の証明から複雑な場合の証明へと 誘導されれば, 複雑な場合の証明も自ら理解し得るにい たるのか。それは結局，てれらの証明が一つの形式を共 有しているからである。そして㬰は，さきの $n$ を $n$ のま まとした証明が，その形式の表現であったわけである。

さて以上のよらであるとすれば， $n=4, n=5, n$ $=6$ といった簡単な場合の証明を理解することは, 奏は 同時に，その形式を理解することに外ならないのであ り，そして多くの場合は，その形式の理解をもって，今 度は $n=10$ よらな複雑な場合の証明の理解を得る, と いらわけなのである。簡単な場合の証明を理解する努力 は, 実は多くの場合, 複雑な場合の証明の形式を理解す るための努力でもあるわけなのである。

しからば，はじめから $n$ を $n$ のままとした証明を理解 しょらとすればよいではないか。なぜなら，それが $n=$ 10の場合の証明の形式の表現であるのだから。しかし， またしてもウイズダムならば言うであろら。具はそれが 不可能なのである、と。なぜなら，nをnのままとした 証明を理解するためには，搏び我々は，例えば $n=4$ の 場合からはじめて, $n=5$ の場合, $n=6$ の場合と, ス テップ・バイ・ステップに進まざるを得ないであろらか ら。いずれにせよ我々は，まず簡単な場合についての具 体的証明を理解せ齐ばならないのである。なぜなら，個 々の具体的証明においてのみ, その今問題の形式は自ら を示すのであるから。

しかし， $n=10$ 場合の証明の理解は，たしかによ り簡単な場合の証明の理解に基ついているとはいえ，そ れはその証明の「理解」に関してであって，その「証明」 そのものは，より簡単な場命の「証明」に基づいてはい ないのではないか。ところが，㱏はそうではないのであ る。なぜなら， $n=4, n=5, n=6$ といった簡単な 場合の証明が成り立たないのに，それと同じ形式で進め られる $n=10$ の場合の証明が成り立つ，という事はあり 
得ず，したがって，その簡単な場合の証明の成立は， $n$ $=10$ の場合の証明の成立の前提であり，かつ， $n=10$ の 場合の証明の形式は，咲は，それの前提をなしていると ころの,より簡単な場合の証明に基ついているのである から。

一体「形式」といらものは，それ自体では存在できな いものである。そ机は，具体的な何かに拈いて在り，そ して，その具体的な何かに揖いて「示される」より他に は，仕様のないものなのである。そして今の場合， $n=$ 10の場合の証明の形式は，それが行なわれる以前には， それよりも簡単な場合の証明において示されているのみ である。それは，具体的には， $n=4, n=5, n=6$ などの場合の証明において，示されているのみである。 そしてそれは，それら簡単な場合の証明に持いて示され ることによって，そしてその限りに拈いてのみ，空虚で はないのである。存在を確保するのである。したがっ て，それ—— $n=10$ の場合の証明の形式一をとれとす るもの, 即ち, それを, 空虚なものではなく, 我々が現 にそれとして理解しているような，そのようなものとす るもの，それは，夷は， $n=4, n=5, n=6$ といっ た簡単な場合の証明に外ならないのである。それら簡単 な場合の証明は, ただ単に学猊の過程, 訓練の過程にお いて踏まれるべき段階であるにとどまらず，契は，それ らこそが，それらが共有する形式に，したがって $n=10$ の場合の証明の形式に，その内容を与えるのである。そ してその意味で， $n=10$ の場合の証明の形式は，それら の，より簡単な場合の証明に基ついているのである。そ れゆえ，たしかに $n=10$ の場合の証明は， $n=4, n=$ $5, n=6$ といった簡単な場合の証明に直接訴兄る必要 はないとしても, しかし, 前者の形式は後者に基ついて いるのである。そしてその意味では，前者は後者に基ず いているのである，と言えよう。

ここまで来れば, ウイズダムの言らことが理解できよ ら。ウイズダムによれば，「 $D_{m}$ だから $E_{m}$ である」と いった演繹的推論の場合も，それは「「 $D_{1}$ のとき $E_{1}$ で ある」,「 $D_{2}$ のとき $E_{2}$ である」, …といった相似物に 基づいた推論なのであるが，それは，当の演繹的推論の 証明の形式が，それら相似物の証明に基ついているから なのである。

\section{4 の 1}

しかし, 以上の例は数学からとられている。しから ば，推論を本来の対象とする論理学においてはどらなの だろらか。論理学に拈いても，やはり「「 $D_{m}$ だから $E_{m}$
である」といった演繹的推論の場合，それは，「D き $E_{1}$ である」，「 $D_{2}$ のとき $E_{2}$ である」……いった 相似物に基づいた推論なのであろらか。ウイズダムによ れば，やはり，実はそうなのである。

たとえば，「 $D_{m}$ (今日は晴である，そして，今日晴で あるならば今日は体育祭である) だから $E_{m}$ (今日は体 育祭)である」といった，典型的な演繹的推論の場合を 考えてみよう。しからば一体この推論は, 何に訴觉て行 なわれるのだろらか。

それは，この場合，「一般に，もし $D_{n}$ ならば $E_{n}$ で ある」といら論理学の一般法則の別表現に外ならないと ころの

$$
\begin{aligned}
& p \\
& p \supset q \\
& \therefore \therefore
\end{aligned}
$$

という, 論理学者が保証する推論の一般法則に訴えて, であろらか。普通はそう思われている。なぜなら，たし かに，当の演繹的推論において，「今日は晴である」を $\lceil P 」 ， 「 今 日 は$ 体育祭である」を「Q」，「そして」を上 下の配置，「ならば」を「つ」，「だから」を「横棒と・・」 で表わせば，それは

$$
\begin{aligned}
& P \\
& P \supset Q \\
& \hline \therefore Q
\end{aligned}
$$

と書き表わせ，そしてこれは（1）の形を有しているか ら。しかし，ここでウイズダムならば問らであろう。 (1)は(2)を含んでいるのだろらか，と。そしてあと は, 数学の場合とほぼ平行した議論が成り立つのである。

もし(1)が(2)を含んでいるとすれば，そして(1)に 訴えることが，そこに含まれている(2)に訴えることで あるとすれば，（1）に訴えることは循環になり，また， もし(1)に訴えることが，そこに含まれている(1)に訴 えることでないとすれば，あるいは，(1)が(2)を含ん でいないとすれば，結局我々は，形の上では(1)に訴兄 てはいるが，その実は，（1)の中に入っている(2)の相 似物に訴えているにすぎない事になるのである。要する に，いずれにせよ(1)は，実際上は何の働きむしていな い事になるのである。一般的に言えば，個々の具体的演 繹においては, 論理の一般法則なるものは不必要である, といら事になるのである。

これに対しては，例えば次のように答えたくなるであ ろう。そのような事が問題になるのは，(1)が論理的に 証明せられていないからであり，一度(1)が論理的に 「証明」せられ，それが一般に成り立つ論理学の一般法 
則になったならば，そのような問題は消隇してしまう, と。そして実際に，その証明をしてみせるのである。そ れは例えば，次のようなものである。

$\Gamma p \supset q$ といら事は， $p$ であって $q$ でないといら事は

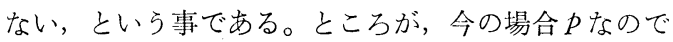
ある。それ沛觉，今の場合我々は， $q$ である，と推論 してよいのである。(証明終り)」

しからば，そのような答の帰結は何であろうか。たし かにこの証明は，あれやこれやの $p ， q$ について成り立


り立つ。即ち,この証明には，(2)の場合の証明も当然 含まれているのである。このことは何を物語っているの か。それは，(1)は(2)を当然含んで扣り，そして(1) に訴光ることは，そこに含まれている(2)に訴光ること である，といら事であろう。しかし今や我々は，(2)の 証明を知っているのである。したがって，（1）訴光る ことは，そこに含ま机ている( 2 似訴えることである， と言ったとしても，そこで言われている事は，実はそれ は（2）の証明汇訴光る，という事に外ならないのであ る。したがって，（1）使光ることが，そこに含ま礼て いる(2) 飞訴えることであるとしても，そ机は決して循 環になりはしないのである。そして確かに，こう考光れ ば，さきのウイズダムの問いに対しては，一応の答を得 ることになるであるう。

しかし，そうだとすれば，(2)の推論を(1)に訴兄る という事は，実は，（2）の証明に訴えるという事，言う なれば，自分自身の証明に訴党るといら事，であって， ここに扔いては，一般的な（1）は本来必要ないことにな るのである。一般的に言えば，個々の具体的な演繹に拉 いては, やはり依然として, 論理学の一般法則は不必要 である,といら事になるのである”。

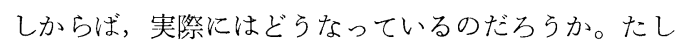
かに，(2)の場合の演繹的推論には，(1)のような一般 法則は不必要である。そこに必要なのは自分自身の「証 明」なのである。そしてたしかに（2）の証明は，或る 意味では，それ自身で成立していると言えよう。それ は，他のそれと相似物な場合の証明に訴光る必要もない のである。しかしここで，ウイズダムならば言らである う。その証明の「理解」は，それと相似物な場合の証明 の理解に基づいているのだ，と。そして，確かにその通 りであろう。なぜなら，それと相似物な場合の証明の理 解なしには，(2)の証明の理解はあり得ざ，そして実際 例光ば（2）の証明を理解できない人がいた場合，その人 にその証明を理解させるには，我々はその人に，先ず
（2）と相似な，しかしよりわかり易い場合の証明をいく つか理解させ，そしてそこからその人を（2）の証明を 理解するよう，導くであるらから。そしてそのような事 が可能なのは，結局，それら互に相似な場合の証明が， 一つの形式を其有しているから，なのである。そして失 は，さきの(1)が，その形式の㳖現であったわけであ る。

ところが，その証明の「理解」ではなく，その「証明」 そのものも，それ之相似な場合の「証明」に基づいてい るのである。なぜなら，(2)と相似な場合の証明が成り 立たないのに，それと同じ形式で進められる(2)の証明 が成り立つ，といら事はあり得ず，したがって，(2)と 相似な場合の証明の成立は，(2)の証明の成立の前提で あり，かつ，(2)の証明の形式は，笑は，それの前提を なしているところの，(2)と相似な，しかしょりわかり 易い場合の証明に基ついているのであるから。この焦 も, 数学の場合と闹じである。

それ的え，たしかに( 2)の証明は，それと相似な場合 の証明に值接訴光る必要はないとしても，しかし，前者 の形式は後者に基づいているのである。そしてその意味 では，前者は後者に基ついているのである。

ここまで来れば,やはりウイズダムの言らことが理解 できよう。論理学においても, やはり，(2)は, それの 相似物に基づいた推論なのである。なぜなら，（2）の証 明の形式は，(2)の相似物の証明に基ついているのだか ら。

\section{4 の 2}

しかし，（2）の証明は，絬局のところ「つ」といら部 号の意味に基づいているのではないか。そしてその記号 の意味なるものは，その記具の真理裴によって与兄られ るのではないか。したがって，（2）の証明は, 絬间のと ころ、「つ」といら記号の真理表に基いいているのみであ って，(2)と相似な場合の証明などには基づいていない のではないか。しかし，実は，それがそうではないので ある。

第一，（2）の証明は決して「つ」といら記光の意味の みに基づいてはいない。それと同じ比重で，「そして」 を表わす上下の配置の意味飞も基ついて求り，そしてお

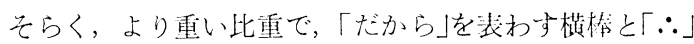
といら暗号の意味にも，基づいているのである。そもそ も，「つ」といら記号には「推論」といら意㕲が入って いない。ところが我々は(2)に扔いて，まさしく「推論」 をしているのである。そして(2)が「推論」であること 
を示しているのが，まさに，「だから」を表わす横棒と 「○」といら院号なのである。しからば我々は，その横 棒と「 $\therefore 」$ の理解を，一体何に基ついて行なうのだろう か。それは結局，（2）と相似な，しかしよりわかり易い 推論の諸事例の理解を通して，そして更には，（2）と相 似でない，しかしょりわかり易い推論の諸事例の理解を 通して，であるち。ここにおいて我々は，(2)の理解 は, 必然的に(2)をはみ出し，(2)と相似な，あるいは 相似でない，もっとわかり易い推論の諸事例の理解に基 つくくのだ，という事を知るのである。

その上，「(2)の証明は，…」と言うが，その「証 明」といらことの理解も, 必然的に(2)をはみ出し, （2）と相似な，あるいは相似でない，もっとわかり易い 証明の諸事例の理解に基づくのである。

そしてこれらの事は，またしても，ただ単に「理解」 に関してのみ䓂光る事ではなく（2）そのもの，そして 「証明」といらことそのものにも，言えるのである。そ してこの事は，これまで述べて来たことから，十分推測 できるであろら。

かくして，いずれにせよ(2)は，少なくともそれの相 似物に不可火に基づいた推論なのである。

\section{5}

以上において見たように，演繹的推論は，数学におい ても論理学においても，相似物に基ついた推論なのであ る。ところが，すでに見たように，単純な㷌納的推論は 類似物に基ついた推論なのである。

しからば，いわゆる仮説演繹法にもとずいて理論を立 ててゆくやり方のような，言らなれば単純でない帰納的 推論の場合はどらなのであろらか。しかし，仮説演繹法 における「仮説の設定」の部分は，いわば「発想」であ って，「推論」ではない。また，テスト可能な命題を導 き出す「演繹」の部分は，今みたように，相似物に基つ いた推論である。そして，テストの結果に基づいた仮説 の判定は, 検証理論の場合は, あまり根拠のない「判 定」であって，これまた「推論」ではなく，反証理論の 場合は，夷は「演繹」であり，したがって，相似物に基 ついた推論なのである。それゆ結局, 仮説演繹法にも とずいて理論を立ててゆくやり方のような，単純でない 㷌納的推論と，言えば言えなくない様な場合について， 改めて考慮する必要はあるまい。

そうだとすれば，すべての推論は，結局は，相似物ま たは類似物に基づいた推論である，と言えよう。しかし 「相似物」は「類似物」を含んでいる。それゆ光結局,
「すべての推論は相似物に基づいた推論である」と言え よう。かくしてこの点で演繹的推論は，一般にそれより 一段低くみられている㷌納的推論と, 実は一一衝撃的に も一同類なのである。

しかしもちろん, 帰納的推論と演繹的推論には, 基本 的な違いがある。それは，前者は事実関係に基づいてい るのに対し，後者は意味関係に基ついている，という事 である。しかし今は，この点に立ち入る余裕がない。こ の小論の論題は,「パラダイム論」であるからである。

\section{6}

しからば，以上の議論は「パラダイム論」といかに関 わるのか。

以上において見たように，ウイズダムによれば，すべ ての推論は相似物に基ついた推論なのである。そこにお いては，一般法則に訴える必要はない。しかし現実に拈 いては一般法則は, 推論において, 大きな役割を演じて いるではないか。その通りである。しからば，その役割 は何なのか。それはしかし結局, 象徵的な役割なのであ る。いわば大きな，しかし象徵的役割なのである。

すでに，さきにあげた諸例に沶いて明らかな如く，一 般法則とは，個々の推論の形式の表現に外ならないので ある。それは，いわば，個々の推論の形式を一括して抽 象的に示し，よって個々の推論の形式を思い起こさせる もの, なのである。これに対し, 個々の推論の形式その ものは, 個々の推論そのものに拀いて在り, そして, 個 々の推論そのものに拈いて示されているのである。した がって, 一般法則が表現せんとするものは, 個々の推論 において示されているものなのであり, それゆえ, 個々 の推論なしには，一般法則は空虚なのである。言い換え れば，一般法則が表現せんとするものを示している個々 の推論がある限りに打いて，そしてその限りに拉てて み，一般法則は空虚ではないのである。そうだとすれ ば，一般法則にその内容を与えるものは，結局は個々の 推論なのであり，そして，一般法則に訴えるという事は その実は，結局はそれに内容を与えている個々の推論に 訴える事に外ならないのである。それゆえ一般法則は， 大きいとはいえ結局はそれに内容を与えている個々の推 論に刘して，象徴的な役割を演じているにすぎないので ある。

そらだとすれば，一般法則を理解するという事は, 結 局はそれに内容を与えている個々の推論を理解する事, それが表現せんとする形式を示している個々の推論を理 解する事，以上のことではない。一般には，そのような 
個々の推論は，一般法則に対して，その「事例」であ る、とされている。一般法則を或る特定な場合について 適用した一つの事例である，といらわけである。そし てたしかに，形式的にはそらであろう。しかし，一般法 則にその内容を与えるものは，逆に，その事例の方なの である。一つも事例のない一般法則, 例光ば, ぞら使っ てよいかわからない一般法則, は，内容のない一般法 則, 空虚な一般法則, であると言光よう。しかし、はじ めはどう使ってよいかわからなかった一般法則も，次第 にその使い方がわかって来て，その事例が多くなって来 れば，それに伴って，その内容も豊かになってゆくので ある。例えばシュレーディンガーの方程式は，そのよう な一般法則の一例であると，2なす事が出来よ $5^{8)}$ 。

シュレーディンガーの方程式は，はじめシュレーディ ンガーによって提出された時は, 彼自身にもその解き方 がわからなかった，と言われる。しかし，ワイルなどの おかげで，その解き方もわかり，具体的な問題に適用さ れ，次第に成功を納めるようになっていった。そしてこ の過程が, 即ち, シュレーディンガーの方程式が内容豊 になってゆく過程なのである。

さて，以上のようであるとすれば，一般法則を理解す るといら事は，それが表現せんとする形式を示している 個々の事例を理解する事，以外ならない。事例抜きの一 般法則の理解といらものは，あり得ないのである。しか も，事例の理解を通して獲得した一般法則の理解は，そ の後も常に事例の理解に裏打ちされているのであり，そ の逆ではない。一般法則の理解には, 事例の理解が先行 し，常に先行し続けるのである。

ここで「事例」を「パラダイム・ケイス」で置き換え れば，以上で言われた事は，言らなれば，理論に対する 「パラダイム・ケイスの優先」，といら事である。もち ろん，一般に「パラダイム」と言われているものは，

「パラダイム・ケイス」を含んだ，もっと広大なもので ある9)。しかし，ここまで来れば，むはや「パラダイム 論」の必然性は明らかであろう。それは，物事を徹底し て，個別に执いて，具体に执いて，ケイス・バイ・ケー スに見ようとする方法一ウイズダムの言う「ケイス・ バィ・ケイスの方法」一の必然的結果であり，いわば 「下からの方法」の必然的結果であって, 物事を一般に 怙いて，抽象に批いて見よらとする方法，いわば「上か らの方法」、対して，対極をなすものである。そ机兄 「パラダイム論」は,「形式主義」や「公理主義」に対し て対極をなすのみならず，ヘンペルやネイゲルで代表さ れるよらな, 一般法則からの推論として「説明」や「還
元」を理解しょうと与る理論に対しても，刘極をなすも のなのである。そして以上の私のくだくだしい不十分な 議論は，それでもこの対極関係において，「パラダイム 論」の方に必然性があることを示していると思う。

もちろん「パラダイム論」,特に现に行なわれているそ れには, 種々の問題がある。特に, それに必然的に伴う かの如き「通約不可能性 (incommensurability)」の主張 には，多くの論ずべき樑刻な問題がある ${ }^{10)}$ 。しかし，今 はそこまで立ち入ることは出来ない。今の私としては， ウイズダムの名を借りた以上の私の議論から，「パラダ イム論」の必然性を見てとって載くことを願らのみであ る。

\section{注}

1） ウイズダムの議論について私が参照できたもの は，次の二点である。

D.C. Yalden-Thomson, The Virginia Lectures, in Wisdom: Twelve Essays (ed.) R. Bambrough, Basil Blackwell (1974) pp. 62 77.

Ilham Dilman, Induction and Deduction: A Study in Wittgenstein, Basil Blackwell (1973) pp. $115 \sim 121$.

2)「帰納的推諭」についてり立ち入った議諭として は，Dilman, ibid Part I をあげて扰く。

3) Yalden-Thomson, ibid. p. 64.

4）但し，この場合は $n$ は 3 上り始まる。

5）この種の問いを立てることが，ウイズダムの議論 の一つの特徵であり，そ机古私はこの種の問い を「ウイズダムの問い」と言うことにする。

6）この種の主張が，ウイズダムの主張の核心であ る。彼は，先う「ウイズダムの問い」を立てるこ とによって, 一般法則の不必要なることを明らか にし, 次にこの種の主張によって, 相似物の必要 なことを主張するのである。

7）実はこれは，ウイトゲンシュタインが1918年に完 成した Tractatus Logico-Philosophicus (Routledge \& Kegan Paul）に招いて展開されている論 理観と, 一面では轨を一にしているのである。彼 は5.132亿招いて，次のよ5に言っている。

「pが $q$ から帰結するならば, 私は $q$ からpを推 論することが出来る。 $p$ は $q$ から導くことが出来 る。

その推論の仕方は，それら二つの命题からのみ耿 り出され㸚ばならない。

それら二つの命題そのもののみが，その推論を正 当化しうる。

その推論を玨当化すると一例えばフレーゲやラ ッセルに捄いて——れている『推論の法則』は 意味を持たず，そして余訃なものであうら。」 ところがこのような論理観は, 形を変克, 変容さ 
れながら，彼の一生を貫ぬいている。彼は，たぶ ん1950年，彼の死の約一伴前, Über Gewißheit (Basil Blackwell) のミ45から§46にかけて, 次の 上うに芦っているのである。

「計算の本新を, 我々は, 〔計算の規則を学ぶこ とによって，ではなく]計算 [そのもの]を学ぶ ことによって，外ったのだ。(中略)最も重要なこ とは，しかし，規則は必要でない，という事であ る。〔たとえ規則がなくとも〕我々から何かが久け ているわけではない。我々は[結果的に]規則に 従った汁算をするのであり，それで十分なのであ る。」(但し〔]は黒崎の挿人)

ここに捒ける「規則」を「一般法則」に置きかえ れば，てれはまさにウイズダムの言う事であ万 う。そしてそれは尖は当然なのである。なぜなら
ウィズダムは，後期のウィトゲンシュタインの哲 学の核心を，最初に把握したイギリスの哲学者で あるのたから。

8）シュレーディンガーの方程式を推論の一般法則と みることに抵抗のある人は，坚はいろいろ問題は めるのだが，例えば「衝突の問題」を考えればよ いと思5。

9）「パラダイム」および「パラダイム論」について の私の理解については，拙著『科学々人間』勁草 書仿（1977）pp. 174〜176 を参照していただきた い。

10）例えば, Derek L. Phillips, Wittgenstein and Scientific Knowledge: A Sociological Perspective, The Macmillan Press (1977) のミ5を見 上。 